\title{
PENINGKATAN PEMBELAJARAN BAHASA ARAB MELALUI PROGRAM IPPBA DALAM KERANGKA MANAJEMEN BERBASIS MADRASAH
}

\section{Ahmad Mujaddid, Siti Qomariyah, Rosiatul Fitriyah, Zakiyah Arifa}

Pascasarjana Universitas Islam Negeri Maulana Malik Ibrahim Malang ahmadmujaddid25@gmail.com,qomariyah.s95@gmail.com, rosiatulfitriyah15@gmail.com, arifazakiyah@uin-malang.ac.id

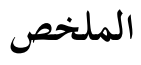

إن هذا البحث يبحث في: () إدارة التخطيط في برنامج IPPBA في مدرسة الثانوية مالانج (، ب) إدارة التنظيم في برنامج IPPBA في مدرسة الثانوية مالانج ا ـ تم تضمين هذا البحث في البحث النوعي الوصفي وطرق جمع البيانات من خلال المقابلات والملاحظة والوثائق. تم تحليل البيانات باستخدام نظرية كريشويل. أما نتائج البحث فهي تخطيط أنشطة برنامج IPPBA على المدى القصير، ويشمل هذا البرنامج على البرامج الأسبوعية هي تعلم اللغة العربية مع المشرف، والبرامج الشهرية هي المناقشة، ونشر النشرة، والتقويم، ثم برامج العرضي (incidental) هي مسابقة اللغة العربية لكل الطلبة. أما البعد المكاني فهي التخطيط الوطني لأن احتفال أنشطة اللغة العربية في المستوى الوطني. أما تخطيط المستوى الفني باستخدام التخطيط القطاعي للطلبة في بحال اللغة العربية، أما نوع التخطيط فهو التخطيط المشترك top down and bottom up) لأن الأنشطة في هذا البرنامج يصمم بشكل مشترك من رئيس البرنامج وأعضائها ومشرفيها مع اتفاق منهم، وشكل الهيكل التنظيمي هو الهيكل الهرمي لذلك رئيس البرنامج له القدرة والقوة في مراقبة كل أنشطة هذه البرنامج·

الكلمات المفتاحية: إدارة; تخطيط; تنظيم; برامج جمعية محبي اللغة العربية; إدارة على أساس المدرسة 


\begin{abstract}
Abstrak
Penelitian ini membahas mengenai : 1) manajemen perencanaan dalam program IPPBA di MAN 1 Kota Malang dan 2) manajemen pengorganisasian dalam program IPPBA di MAN 1 Kota Malang. Penelitian ini menggunakan penelitian kualitatif deskriptif dengan metode pengumpulan data dengan wawancara, observasi, dan dokumentasi. Setelah data terkumpul dilakukan analisis data dengan menggunakan teori Jhon Creswell. Hasil penelitian yang diperoleh ialah kegiatan program IPPBA ini menggunakan perencanaan jangka pendek karena terdiri dari Program mingguan yaitu belajar bersama dengan tutor sebaya, dan program bulanan yaitu munaqosyah, menerbitkan buletin dan evaluasi, serta program insidental yaitu adanya perlombaan gebyar bahasa arab untuk para siswa. Untuk dimensi spasial menggunakan perencanaan nasioal karena ada event gebyar bahasa arab yang terlaksana ditingkat nasional. Untuk tingkatan teknis perencanaan menggunakan perencanaan sektoral karena untuk mencerdaskan para siswa di bidang bahasa arab. Adapun jenis perencanaannya adalah top-down dan bottom-up karena kegiatan yang ada dalam program ini dirancang secara bersama oleh ketua, para anggotanya dan tutor serta atas kesepakatan bersama. Bagan struktur organisasi di IPPBA ini menggunakan bagan struktur piramidal dilihat dari bagannya posisi tertinggi dalam kewenangan mengatur dan mengkontrol setiap tugas ada pada ketua.
\end{abstract}

Kata Kunci : Manajemen; Perencanaan dan Pengorganisasian; Program Ikatan Pelajar Pecinta Bahasa Arab (IPPBA); Manajemen Berbasis Madrasah.

\title{
A. Pendahuluan
}

Manajemen Program Madrasah adalah salah satu strategi untuk menciptakan madrasah yang produktif dan siap bersaing dengan lembaga-lembaga madrasah yang lainnya ditingkat antar madrasah. Manajemen program ini merupakan manajemen berbasis madrasah karena madrasah adalah salah satu lembaga pendidikan yang diberikan otonomi untuk mewujudkan reformasi pendidikan, Madrasah juga mempunyai kekuasaan dan tanggung jawab penuh dalam menetapkan programprogram pendidikan yang harus diterapkan di madrasah guna meningkatkan mutu dari madrasah itu sendiri serta mempunyai kebebasan dalam menetapkan berbagai kebijakan yang sesuai dengan apa yang menjadi visi, misi dan tujuan dalam pendidikan (Manab, 2015: 107-108). Untuk mewujudkan segala yang menjadi visi, 
misi dan tujuan madrasah itu akhirnya madrasah dituntut untuk mewujudkan dan melaksanakan berbagai program serta kegiatan yang dapat membangun mutu pendidikan di lingkungan madrasah itu, serta dapat mempertanggung jawabkannya kepada masyarakat dan pemerintah sebagai bagian dari lembaga pendidikan yang ada di Indonesia.

Salah satu program madrasah yang tujuannya untuk mengarahkan minat dan bakat siswa dalam meningkatkan kemampuannya dalam Bahasa Arab yaitu adanya program yang diselenggarakan di Madrasah Aliyah Negeri (MAN) 1 Kota Malang yang bernama Ikatan Pelajar Pecinta Bahasa Arab (IPPBA). Sehingga di IPPBA inilah terdapat sekumpulan siswa-siswi yang mempunyai minat dan bakat di bidang kebahasa araban.Para anggota IPPBA bersama dengan pembinanya menyelenggarakan kegiatan-kegiatan kebahasa araban misalnya pembelajaran bahasa Arab tutor sebaya, permainan bahasa Arab, menyanyi lagu berbahasa Arab baik yang asli maupun terjemahan. Sehingga IPPBA akan mempunyai hajat besar yaitu memeriahkan hari Bahasa Arab se-dunia karena di madrasah inilah tempat terselenggaranya berbagai macam mata lomba tingkat madrasah untuk mengasah kemampuan para siswa dan siswi dalam kemampuan bahasa arab mereka.

Alasan kami memilih program IPPBA ini adalah kami ingin mengkaji bagaimana proses atau cara yang dilakukan oleh guru dalam melaksanakan manajemen program inisehingga dapat memberikan khazanah keilmuwan bagi para peneliti dan sejauhmana tingkat keberhasilan yang dicapai dari program ini dalam mengembangkan ilmu bahasa arab itu bagi para siswa dan siswi khususnya yang ada di MAN 1 Kota Malang tersebut.

Untuk mencapai kepada tujuan yang baik pastilah terdapat perencanaan dan pengorganisasian yang baik pula dalam melaksanakan program IPPBA tersebut. Banyak prestasi yang didapat dari adanya program ini dan tingkat keberhasilan tersebut tidak terlepas dari manajemen yang utama bagaimana para pendidik di IPBBA ini menjalani fungsi manajemen tersebut dengan baik dari segi bagaimana cara para pendidik membuat perencanaan dan pengorganisasian program di IPPBA 
ini sehingga perlu diteliti hal-hal yang berkaitan denganmanajemen perencanaan dan pengorganisasian pada Program ekstra kulikuler IPPBA ini.

Berdasarkan pemaparan diatas, maka peneliti akan memfokuskan penelitiannya pada : 1) Bagaimana manajemen perencanaan dalam program IPPBA di MAN 1 Kota Malang? dan 2) Bagaimana manajemen pengorganisasian dalam program IPPBA di MAN 1 Kota Malang?

\section{B. Landasan Teori}

\section{Manajemen Berbasis Madrasah}

Manajemen program madrasah atau disebut dengan manajemen berbasis madrasah (MBM) merupakan strategi untuk mewujudkan madrasah yang efektif dan produktif, hal ini merupakan salah satu wujud reformasi pendidikan yang memberikan otonomi kepada madrasah untuk mengatur kehidupan sesuai dengan potensi, tuntutan, dan kebutuhannya. Otonomi diberikan agar madrasah leluasa mengelola sumber daya, sumber dana, sumber belajar dan mengalokasikannya sesuai prioritas kebutuhan, serta lebih tanggap terhadap kebutuhan setempat. Madrasah juga mempunyai kekuasaan dan tanggung jawab penuh dalam menetapkan program-program pendidikan yang harus diterapkan di madrasah guna meningkatkan mutu dari madrasah itu sendiri serta mempunyai kebebasan dalam menetapkan berbagai kebijakan yang sesuai dengan apa yang menjadi visi, misi dan tujuan dalam pendidikan (Manab, 2015: 107-108). Untuk mewujudkan visi, misi dan tujuan itu akhirnya madrasah dituntut untuk menetapkan berbagai program dan kegiatan di lingkungan madrasah itu sendiri serta dapat mempertanggung jawabkannya kepada masyarakat dan pemerintah.

\section{Karateristik Manajemen Berbasis Madrasah}

Sebagai bentuk operasional dalam desentralisasi pendidikan dalam konteks otonomi daerah MBM diharapkan dapat membawa dampak baik dalam peningkatan efisiensi dari efektivitas kinerja madrasah, dengan menyediakan layanan pendidikan yang komprehensif dan tanggap kepada kebutuhan masyarakat. Dengan MBM ini madrasah diharapkan mampu meningkatkan mutu 
dan kualitas serta dapat bertanggung jawab kepada masyarakat dan pemerintah. Adapun karakteristik MBM bisa diketahui dari bagaimana madrasah itu dapat mengoptimalkan kinerjanya, proses pembelajaran, pengelolaan sumber belajar, profesionalisme tenaga pendidikan serta sistem administrasi secara keseluruhan (Manab, 2015: 108). Supaya sekolah atau madrasah dapat melakukan seluruh aktivitas kerjanya maka perlunya adanya pemberian otonomi luas kepada Madrasah, dan tingginya partisipasi masyarakat dan orang tua untuk mendukung program atau kinerja yang ada di Madrasah, karena keterlibatan masyarakat dan orang tua sangat penting dalam hal ini serta seorang pemimpin atau kepala sekolah harus memiliki sifat dan komitmen yang demokratis dan profesional didalam menjalani fungsi tugasnya sebagai leadership.

\section{Manajemen Perencanaan}

\section{a. Pengertian Manajemen Perencanaan}

William H. Newman dalam bukunya Administrative Action Techniques of Organization and Management Perencanaan adalah memilih atau menentukan sesuatu untuk dilakukan. Dalam perencanaan terdapat serangkaian keputusan yang luas dan juga beberapa penjelasan dari tujuan, ketentuan kebijakan, ketentuan program, ketentuan metode dan prosedur dan juga ketentuan kegiatan yang dilakukan setiap hari sesuai dengan jadwal yang sudah ditetapkan (Majid, 2005: 16).

Menurut Sergiovanni dan Syaiful Sagala : Perencanaan adalah tuntutan, taksiran tujuan, posisi pedoman yang menjadi patokan dan pernyataan keputusan yang telah ditetapkan dan tidak bisa diubah lagi, dalam periode jangka waktu panjang atau jangka waktu pendek yang telah mendapatkan kesepakatan bersama oleh pimpinan dan staf lembaga (Yusuf, 2009: 24).

b. Ruang Lingkup Perencanaan.

Dimen swaktu, spasial dan tingkatan teknik perencanaan sangatlah berpengaruh dalam ruang lingkup perencanaan (Usman, 2008: 60), ketiga 
Dimensi tersebut saling berkaitan antara satu dengan yang lainnya sebagai berikut:

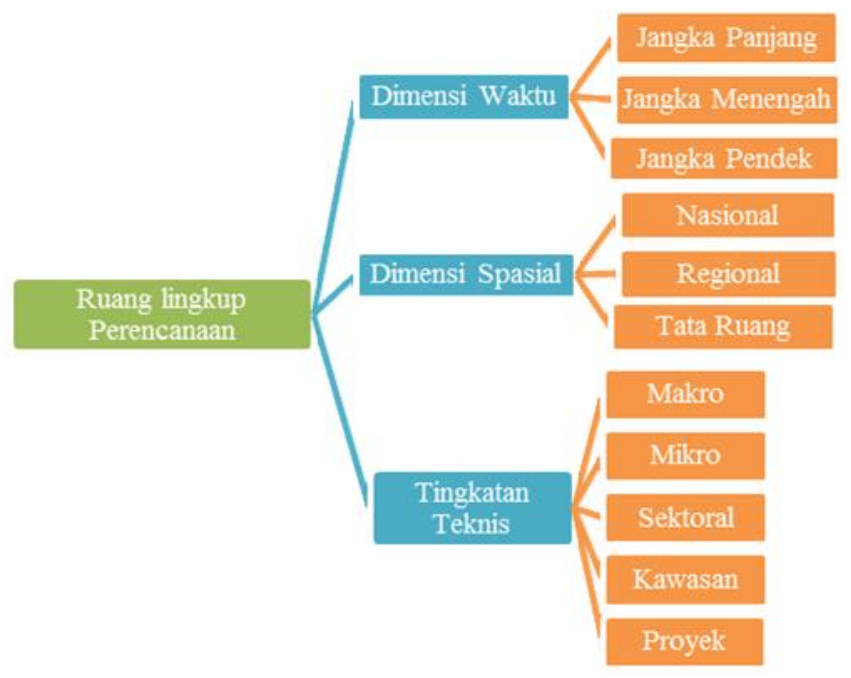

1) Perencanaan dari Segi Dimensi Waktu

a) Perencanaan Jangka Panjang (Long Time Planning)

Dalam perencanaan ini memiliki jangka waktu 4 hingga 8 tahun lebih untuk lingkungan kemendikbud. Contoh: Propenas.

b) Perencanaan Jangka Menengah (Medium Term Planning)

Dalam perencanaan ini memiliki jangka waktu 1 hingga 4 tahun di lingkungan kemendikbud. Contoh: Propeda atau jika di lingkungan sekolah seperti Rencana Kerja Sekolah (RKS)

c) Perencanaan Jangka Pendek

Dalam perencanaan ini memiliki jangka waktu maksimal 1 tahun untuk kemendikbud. Contoh: Perencanaan oprasional tahunan, rencana kegiatan dan anggaran sekolah.

2) Perencanaan dari Segi Dimensi Spasial

Ruang dan batasan wilayah sangat berkaitan dengan karakter yang dimiliki oleh perencanaan spasial. Perencanaan ini meliputi:

a) Perencanaan Nasional: penyusunan kerangka kerja berskala nasional. Contoh: Propenas 
b) Perencanaan Regional: perencanaan daerah atau wilayah

c) Perencanaan Tata Ruang: perencanaan yang berupaya memanfaatkan fungsi kawasan-kawasan tertentu dan menggembangkannya. Contoh: perencanaan pemukiman, perencanaan kota.

3) Perencanaan dari Tingkatan Teknis Perencanaan

a) Makro: perencanaan yang menyangkut tentang ekonomi dan non ekonomi dari segi internal maupun eksternal.

b) Mikro: perencanaa yang disesuaikan dengan pendapatan daerah dibidang pendidikan.

c) Sektoral: Perencanaa Program dan kegiatan-kegiatan pendidikan untuk mencapai tujuan pendidikan nasional.

d) Kawasan: Perencanaan yang dilihat dari lingkungannya.

e) Proyek: Perencanaan yang menyangkut pembangunan.

c. Macam-macam Perencanaan

Ada beberapa macam perencanaan dibawah ini (usman, 2008: 85-86):

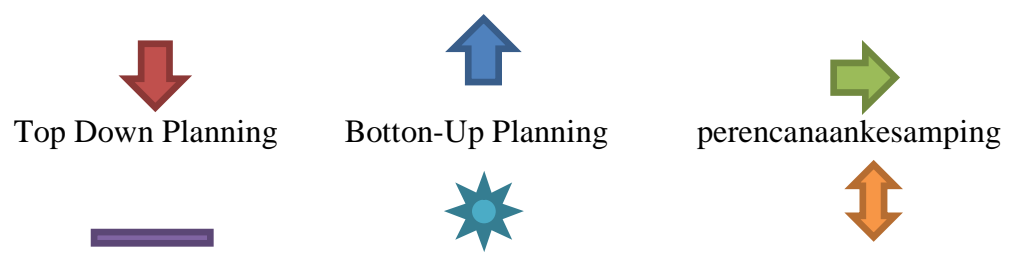

Horizontal Planning Rolling Planning Top Down \&Botton Up

1) Top Down Planning: Pemimpin yang membuat perencanaan dalam organisasi.

2) Bottom-Up Planning: perencanaan dibuat oleh anggota untuk disampaikan pada pemimpin.

3) Perencanaan Menyerong Kesamping: perencanaan dibuat pemimpin dengan pemimpin lain diluar organisasi.

4) Perencanaan Mendatar: Perencanaan lintas sektoral 
5) Perencanaan Menggelinding: pemimpin membuat perencanaan jangka panjang, jangka menengah dan juga jangka pendek.

6) Perencanaan Gabungan: dibuat oleh pemimpin dan juga anggotanya untuk kepentingan organisasi yang melibatkan partisipasi aktif keduanya.

\section{Manajemen Pengorganisasian}

a. Proses Pengorganisasian

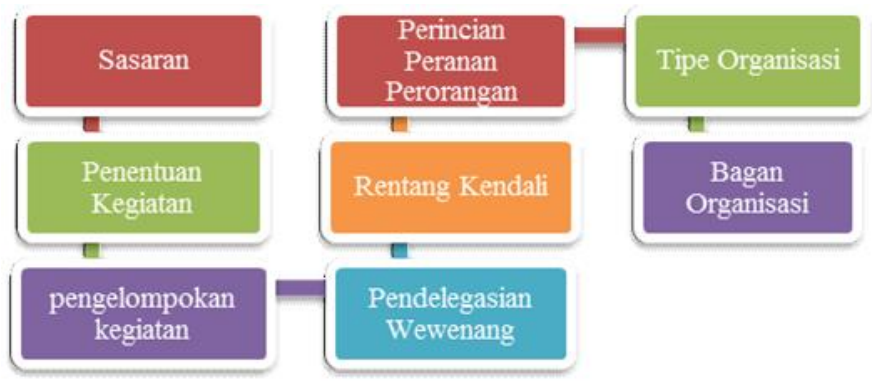

Langkah-langkah manajemen untuk menghasilkan kegiatan pada proses pengorganisasian sebagai berikut:

1) Sasaran: Pemimpin harus tahu tujuan organisasinya.

2) Penentuan kegiatan: Pemimpin harus tahu kegiatan-kegiatan yang akan dilaksanakan dengan menyusun daftar kegiatan tersebut agar tercapainya tujuan organisasi.

3) Pengelompokan kegiatan: Pemimpin mengelompokkan kegiatan-kegiatan dalam satu unit atau satu departemen.

4) Pendelegasian Wewenang: Pemimpin menetapkan wewenang yang akan diberikan pada setiap departemen.

5) Rentang Kendali: Pemimpin menentukan jumlah orang yang terdapat dalam setiap departemen.

6) Perincian peranan perorangan: Pemimpin menetapkan tugas setiap orang.

7) Tipe organisasi: Pemimpin menentukan tipe organisasi, apa yang harus dicapai. 
8) Bagan organisasi: Pemimpin membuat struktur organisasi sesuai yang telah terbentuk. (Marno, 2008: 18-19)

b. Struktur Organisasi

Struktur organisasi adalah kerangka kerja yang telah disusun dan dikoordinasikan oleh pemimpin pada setiap anggota organisasi untuk menjalankan aktivitas organisasi. Dalam proses menentukan pembagian kerja tersebut adalah desain organisasi. Berikut Prinsip-prinsip untuk mendesain struktur organisasi:

\section{Division Of Work (Pembagian Kerja)}

Unity Of Comand (Kesatuan Komando)

Authority (Wewenang)

Span Of Control (Rentang Kendali)

\section{Departementalizatrion (Depertamentalisasi)}

1) Devision of Work (Pembagian Kerja)

Dalam pembagian kerja organisasi ada tiga cara sebagai berikut (Wahab, 2008: 40-50):

a) Pekerjaan dibagikan sesuai dengan bidang keahliannya.

b) Pekerjaan dibagikan dalama ktivitas yang berbeda sesuai dengan pekerjaan yang ada di organisasi.

c) Pekerjaan dibagikan dengan arah vertical.

2) Unity Of Comand (Kesatuan Komando): Anggotahanya boleh memiliki satu pemimpin yang bertanggung jawab secara langsung. Kesatuan komando ini sangatlah penting untuk mencegahnya kerancuan dalam memerintah setiap anggota.

3) Authority (Wewenang): Pemimpin mempunyai wewenang untuk memerintah setiap anggotanya dan agar dipatuhi oleh setiap anggota.

4) Span Of Control (Rentang Kendali): Pemimpin menentukan jumlah bawahannya agar efektif dan efisien. 
5) Departementalization (Depertamentalisasi) : pemimpin mengelompokkan anggota beserta tugasnya.

Bentuk-bentuk struktur organisasi ada dua yaitu:

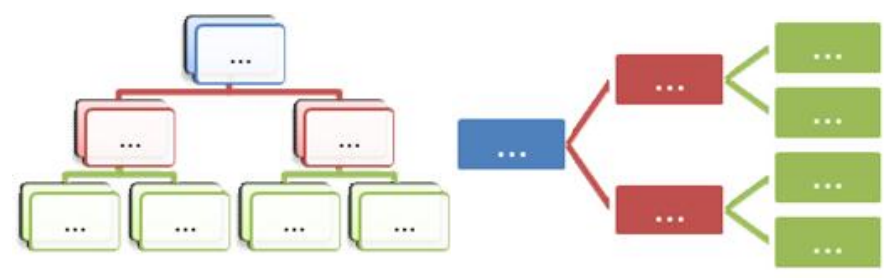

Struktur Organisasi Piramidal - Struktur Organisasi Mendatar

\section{Metode Penelitian}

\section{Jenis Penelitian}

Penelitian ini menggunakan metode penelitian kualitatif yang bersifat deskriptif. Yaitu peneliti mendeskripsikan program ekstra kulikuler yang diselenggarakan di Madrasah Aliyah Negeri (MAN) kota Malang yang bernama Ikatan Pelajar Pecinta Bahasa Arab (IPPBA) dalam hal perencanaan dan pengorganisasian program tersebut. Data primer dalam penelitian ini ialah kabag. Kemahasiswaan dan ketua program IPPBA, sedangkan data sekunder ialah berasal dari dokumen - dokumen yang ada pada program IPPBA mulai dari profil, program kerja, struktur kepengurusan dan anggaran keuangan.

\section{Teknik Pengumpulan Data}

Teknik Pengumpulan data yang digunakan dalam penelitian ini adalah observasi, wawancara dan dokumentasi di Madrasah Aliyah Negeri 1 Kota Malang. Wawancara yang digunakan ialah wawancara tidak terstruktur karena dalam penelitian ini peneliti ingin mendapatkan informasi yang lebih dalam terkait program IPPBA. Observasi yang digunakan oleh peneliti ialah observasi partisipasi pasif yaitu peneliti mendatangi tempat kegiaan yang akan diteliti akan tetapi tidak ikut bergabung secara khusus dalam kegiatan tersebut (Sugiyono, 
2017: 310). Sedangkan, dokumentasi ialah untuk menjadi pelengkap teknik pengumpulan data observasi dan wawancara (Sugiyono, 2017: 329).

Berikut penjelasan dari tiga teknik dan data apa saja yang peneliti peroleh:

Table 1

\begin{tabular}{|c|c|c|c|c|}
\hline No & $\begin{array}{l}\text { Teknik } \\
\text { Pengumpulan } \\
\text { Data }\end{array}$ & Sumber Data & $\begin{array}{ll}\text { Data yang } \\
\text { diperoleh }\end{array}$ & $\begin{array}{l}\text { Instrumen } \\
\text { Penelitian }\end{array}$ \\
\hline 1 & Observasi & & $\begin{array}{l}\text { Data primer } \\
\text { - Situasi kelas dan } \\
\text { lapangan yang } \\
\text { digunakan } \\
\text { - Kondisi anggota }\end{array}$ & $\begin{array}{l}\text { Observasi } \\
\text { partisipasi } \\
\text { pasif }\end{array}$ \\
\hline 2 & Wawancara & $\begin{array}{l}\text { Waka } \\
\text { Kesiswaan }\end{array}$ & $\begin{array}{l}\text { Data primer } \\
\text { - Latar belakang } \\
\text { berdirinya } \\
\text { - Tujuan program } \\
\text { - Pengembangan }\end{array}$ & $\begin{array}{l}\text { Wawancara } \\
\text { tidak } \\
\text { terstruktur }\end{array}$ \\
\hline 3 & Wawancara & Ka. IPPBA & $\begin{array}{l}\text { Data primer } \\
\text { - } \text { kegiatan } \\
\text { - } \text { Guru yang } \\
\text { mengajar } \\
\text { - } \text { Anggaran } \\
\text { kegiatan } \\
\text { - } \text { Kepengurusan }\end{array}$ & $\begin{array}{l}\text { Wawancara } \\
\text { tidak } \\
\text { terstruktur }\end{array}$ \\
\hline 4 & Dokumentasi & $\begin{array}{l}\text { Dokumen } \\
\text { program } \\
2018\end{array}$ & $\begin{array}{l}\text { Data sekunder } \\
\text { - Visi - misi } \\
\text { - Tujuan } \\
\text { - Struktur }\end{array}$ & Dokumentasi \\
\hline
\end{tabular}




\begin{tabular}{|l|l|l|l|}
\hline & & kepengurusan \\
- & Program kerja & \\
\hline
\end{tabular}

\section{Validasi Data}

Strategi validitas data yang digunakan dalam penelitian ini ialah triangulasi (triangulate) yaitu dengan memeriksa kembali seluruh bukti yang dihasilkan dari sumber - sumber tersebut (Creswell, 286). Jadi peneliti melakukan pemerikasaan kembali kepada data - data yang dihasilkan dari sumber data baik dari data primer maupun dari data sekunder yang dihasilkan dari observasi, wawancara dan dokumentasi.

\section{Teknik Analisis Data}

Setelah data terkumpul, peneliti melakukan analisis data dengan teknik analisis data deskriptif. Menurut Jhon Creswell langkah - langkah menganalisis data ada 6 tahapan : 1) mengolah dan mempersiapkan data untuk dianalisis mulai data dari hasil observasi, wawancara dan dokumentasi lalu mengetik data, menyusun dan menggolongkan pada jenis - jenisnya. 2) membaca keseluruhan data, pada tahap ini peneliti membaca ulang data yang telah diketik dan disusun menurut jenisnya lalu mencari data - data khusus atau gagasan umum dari data tersebut. 3) menganalisis lebih detail dengan meng-coding data yaitu pada tahap ini peneliti memberi label pada data - data yang sejenis. 4) mendeskripsikan orang -orang, kategori - kategori, setting dan tema - tema yang akan dibahas. Pada tahap ini peneliti memberi informasi tentang data yang dihasilkan secara detail. 5) menyajikan kembali dalam bentuk narasi. 6) menginterpretasi data, dalam penelitian ini peneliti akan memberikan informasi terkait hasil penelitiannya apakah penelitian ini mendukung, menambah atau menyangkal penelitian sebelumnya (Creswell, 274).

\section{Hasil Penelitian}

\section{Manajemen Perencanaan Program IPPBA MAN 1 Kota Malang}

a. Ruang Lingkup Perencanaan 
Sesuai hasil wawancara kepada Ka. IPPBA ada 3 dimensi yang mempengeruhi ruang lingkup perencanaan program IPPBA yaitu dimensi waktu, spasial dan teknis, dimensi - dimensi ini saling berkaitan. Dimensi waktu termasuk dalam perencanaan jangka pendek karena terdiri dari program mingguan, bulanan dan insidental. Dan untuk dimensi spasial yaitu nasional karena untuk kegiatan incidental sudah masuk wilayah nasional. Lalu untuk dimensi teknis termasuk dalam perencanaan sektoral karena karena salah satu tujuan program ini ialah untuk menambah khazanah keilmuan dan keterampilan dalam bidang bahasa arab (Dzulqifly, wawancara, 1 Desember 2018).

\section{Manajemen Pengorganisasian Program IPPBA MAN 1 Kota Malang}

a. Proses Pengorganisasian

1) Sasaran

Menurut waka kesiswaan, didalam sasaran ini ketua IPPBA bertujuan untuk menambah pengalaman dan menggali bakat dan minat para siswa dalam Bahasa arab. Seluruh anggota ikatan pelajar pecinta Bahasa arab (IPPBA) dan juga seluruh warga MAN 1 Malang (Yasin, wawancara, 30 November 2018).

2) Penentuan Kegiatan

Sesuai dengan data dokumen yang didapat dari agenda kegiatan IPPBA (2018), diadakannya pertemuan rutin, pembayaran kas setiap hari sabtu, untuk setiap bulannya diadakan evaluasi, munaqosah dan pembuatan buletin. Setiap tahunnya juga mengadakan beberapa lomba Bahasa arab yang diikuti oleh semua siswa-siswi MAN 1 Malang.

3) Pengelompokan Kegiatan

Sesuai dengan data dokumen yang didapat dari agenda kegiatan IPPBA (2018), adalah sebagai berikut :

Table 2 


\begin{tabular}{|c|c|c|c|}
\hline No & Kegiatan & $\begin{array}{c}\text { Waktu } \\
\text { Pelaksanaan }\end{array}$ & Tempat \\
\hline 1 & $\begin{array}{c}\text { Pembelajaran dari buku al } \\
- \text { Miftah Sidogiri }\end{array}$ & Minggu ke -1 & Ruang kelas \\
\hline 2 & Muhadatsah & Minggu ke -2 & Ruang kelas \\
\hline 3 & Game bahasa Arab & Minggu ke -3 & $\begin{array}{c}\text { Halaman MAN 1 } \\
\text { Kota Malang }\end{array}$ \\
\hline 4 & Munaqosyah & Minggu ke -4 & Ruang kelas \\
\hline 5 & Pembuatan bulletin & 1 bulan 1 kali & $\begin{array}{c}\text { Kantor } \\
\text { ekstrakulikuler }\end{array}$ \\
\hline 6 & Evaluasi ekstra & 1 bulan 1 kali & $\begin{array}{c}\text { Ruang kelas \& } \\
\text { Kantor } \\
\text { ekstrakulikuler }\end{array}$ \\
\hline 7 & Perlombaan & 1 tahun 1 kali & $\begin{array}{c}\text { Sekolah MAN 1 } \\
\text { Kota Malang }\end{array}$ \\
\hline 8 & Mengikuti event & 1 tahun 1 kali & $\begin{array}{c}\text { Di tempat lomba } \\
\text { diadakan }\end{array}$ \\
\hline kompetensi (pecan araby) & Mengikuti event & 1 tahun 1 kali & $\begin{array}{c}\text { Kampus UIN } \\
\text { Malang }\end{array}$ \\
\hline
\end{tabular}

4) Pendelegasian Wewenang

Menurut Ketua IPPBA, Di IPPBA ketua memegang penuh terhadap wewenangnya, jika ketua tidak hadir maka wakil ketua bisa menggantikannya. IPPBA ini diketuai oleh: Fawaz Dzulqifly, dia merupakan delegasi dari pilihan pelatih IPPBA ini, kemudian banyak anggota IPPBA yang memilih Fawaz sebagai pemimpin yang layak menjadi ketua IPPBA (Dzulqifly, wawancara, 1 Desember 2018).

Kemudian untuk sekertaris, bendahara, devisi pembelajaran, devisi 
Kegiatan, devisi humPubdekdok, devisi Perlengkapan dan devisi konsumsi, ketua IPPBA menunjuk secara langsung para anggotanya sesuai dengan keahlinnya (Dzulqifly, wawancara, 1 Desember 2018).

5) Rentang kendali

Ketua menentukan jumlah perdevisi sesuai dengan keahlian yang dimiliki anggotanya (Dzulqifly, wawancara, 1 Desember 2018).

6) Bagan Organisasi (Arsip dokumen program IPPBA, 2018)

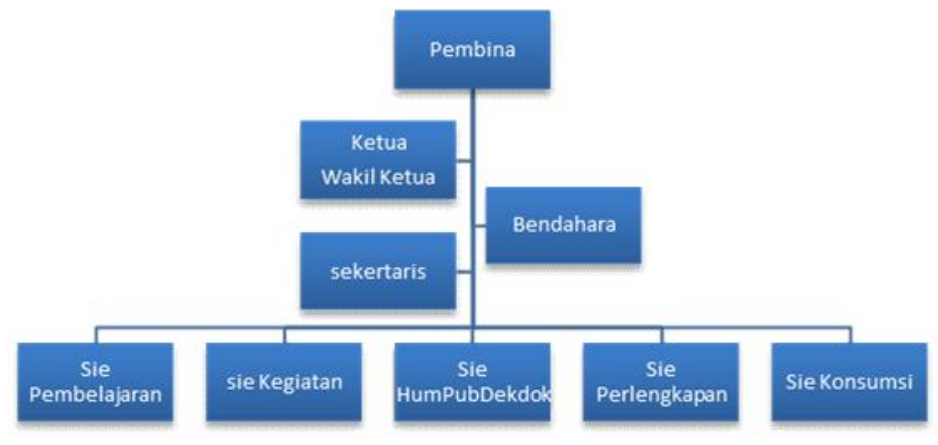

Bentuk Struktur Organisasi : Struktur Organisasi Piramidal

b. Struktur Organisasi

1) Pembagian Kerja

Menurut ketua IPPBA, dalam Pembagian kerja ini, Ketua IPPBA membaginya secara langsung sesuai dengan keahlian yang dimiliki oleh anggota, ketua memantau anggotanya yang mahir dalam bidang nahwu dan shorof maka akan dimasukkan dalam Sie Pembelajaran, begitu juga dengan yang lainnya (Dzulqifly, wawancara, 1 Desember 2018).

2) Kesatuan Komando

Menurut ketua IPPBA, IPPBA ini hanya memiliki satu komando yaitu Komando dari ketua saja, sebab ketua inilah yang bertanggung jawab secara langsung dalam semua aktifitas ataupun kegiatan-kegiatan yang dilaksanaan oleh IPPBA ini (Dzulqifly, wawancara, 1 Desember 2018).

3) Wewenang 
Ketua yang memegang penuh wewenang yang ada dalam organisasi IPPBA ini, jika ketua berhalangan hadir maka wakil yang menggantikannya (Dzulqifly, wawancara, 1 Desember 2018).

\section{4) Rentang Kendali}

Menurut ketua IPPBA, Ketua bersama dengan pengurus inti membagi jumlah anggota perdevisi sesuai dengan keahliannya masingmasing sehingga semua anggota masuk ke dalam devisi-devisi yang ada (Dzulqifly, wawancara, 1 Desember 2018).

5) Depertamentalisasi (Arsip dokumen program IPPBA, 2018)

Tabel 3

\begin{tabular}{|c|c|c|}
\hline Jabatan & Nama & Rincian Perorangan \\
\hline Ketua & Fawaz Dzulqifly & $\begin{array}{l}\text { - Sebagai penanggung jawab dan } \\
\text { pemimpin organisasi sesuai ketentuan } \\
\text { yang berlaku dimadrasah } \\
\text { - Memberikan pengarahan terhadap } \\
\text { seluruh anggota untuk berjalannya } \\
\text { kegiatan organisasi }\end{array}$ \\
\hline Wakil Ketua & Ismi Malika Mufti & $\begin{array}{l}\text { - Melaksanakan tugas ketua apabila } \\
\text { ketua berhalangan hadir } \\
\text { - Memimpin rapat dan menjalankan } \\
\text { tugas sehari-hari }\end{array}$ \\
\hline $\begin{array}{l}\text { Sekertaris I } \\
\text { Sekertaris II }\end{array}$ & $\begin{array}{l}\text { Mufidah Hidayatul I } \\
\text { Nilna Sa'adatus }\end{array}$ & $\begin{array}{l}\text { - Bersama ketua mencari jalan keluar } \\
\text { untuk memecahkan sebuah } \\
\text { permasalahan dalam organisasi } \\
\text { - Membuat surat menyurat untuk semua } \\
\text { perizinan dalam acara baik didalam } \\
\text { maupun diluar Madrasah }\end{array}$ \\
\hline Bendahara I & Apsari Shafa & - Bersama ketua dan \\
\hline
\end{tabular}




\begin{tabular}{|c|c|c|}
\hline Bendahara II & Fina Alisa Q & $\begin{array}{l}\text { bertanggung jawab atas pengolahan } \\
\text { keuangan yang ada dalam organisasi } \\
\text { - Membuat laporan keuangan baik yang } \\
\text { digunakan untuk keluar atau } \\
\text { masuknya kegiatan. }\end{array}$ \\
\hline $\begin{array}{l}\text { Devisi } \\
\text { Pembelajaran }\end{array}$ & Farah Wardah & $\begin{array}{l}\text { - Mengatur jalannya materi dalam } \\
\text { ekstrakulikuler } \\
\text { - Memberi materi yang telah ditentukan }\end{array}$ \\
\hline $\begin{array}{l}\text { Devisi } \\
\text { Kegiatan }\end{array}$ & Shofi Ananda & $\begin{array}{l}\text { - Mengatur jalannya kegiatan } \\
\text { pembelajaran } \\
\text { - Mengatur dan merencanakan kegiatan } \\
\text { event IPPBA }\end{array}$ \\
\hline $\begin{array}{l}\text { Devisi } \\
\text { Humpubdek }\end{array}$ & Widya Azura & 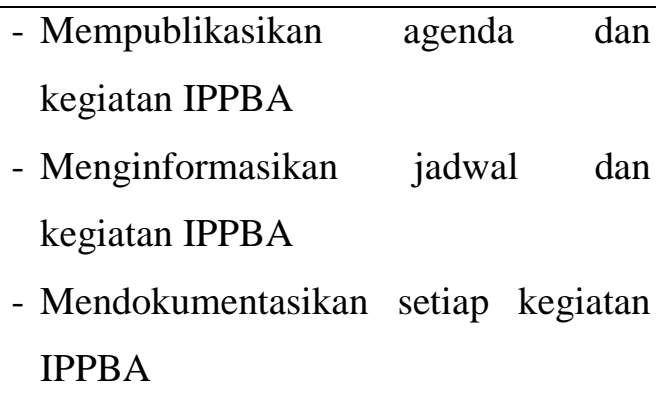 \\
\hline $\begin{array}{l}\text { Devisi } \\
\text { Perlengkapan }\end{array}$ & $\begin{array}{l}\text { Muhammad } \\
\text { Hafiduddin }\end{array}$ & $\begin{array}{l}\text { - Menyediakan property yang } \\
\text { dibutuhkan saat pembelajaran } \\
\text { - Membantu persiapan pra kegiatan } \\
\text { - Mengatur seluruh kegiatan pada event } \\
\text { IPPBA }\end{array}$ \\
\hline $\begin{array}{l}\text { Devisi } \\
\text { Konsumsi }\end{array}$ & Nailatul Izza & $\begin{array}{l}\text { - Mengatur konsumsi pada event } \\
\text { IPPBA } \\
\text { - Menyediakan Konsumsi untuk } \\
\text { kegiatan }\end{array}$ \\
\hline
\end{tabular}

\section{E. Pembahasan}




\section{Manajemen Perencanaan ProgramIPPBA MAN 1 Kota Malang}

Proses perencanaan merupakan langkah awal yang dilakukan oleh seluruh anggota program IPPBA di Madrasah ini untuk meningkatkan kemampuan bahasa arab dan menambah kecintaan siswa dalam berbahasa arab di program ini. Sejalan dengan pendapat Manab (2015: 107-108), Madrasah mempunyai kekuasaan dan tanggung jawab penuh dalam menetapkan program-program pendidikan yang harus diterapkan di madrasah guna meningkatkan mutu dari madrasah itu sendiri serta mempunyai kebebasan dalam menetapkan berbagai kebijakan yang sesuai dengan apa yang menjadi visi, misi dan tujuan pendidikan.

Hasil perencanaan di program IPPBA ini yaitu perencanaannya menggunakan perencanaan jangka pendek, hal ini sesuai dengan teori yang mengatakan bahwa perencanaan jika dilihat dari segi dimensi waktunya ada perencanaan jangka pendek yang dikatakan bahwa Dalam perencanaan ini memiliki jangka waktu maksimal 1 tahun untuk wilayah kemendikbud (Usman, 2008: 60). Karena perencanaan ini terdiridari program mingguan, bulanan dan incidental sehingga program ini hanya dibuat sampai jangka 1 tahun saja tanpa ada jangka menengah dan jangka panjangnya melebihi dua, tiga atau empat tahun karena semua itu sudah menjadi kesepakatan antar anggota sesuai dengan teori yang mengatakan bahwa perencanaan mempunyai wilayah yaitu yang menyangkut satu pihak, dua pihak atau tiga pihak. Sehingga maasing-masing tersebut harus didiskusikan dan disepakati bersama. Dan hasil kesepakatan itu menjadi komitmen bersama dan mendapat dukungan dari semua stakeholder madrasah (Syukur, 2015: 474).

Kegiatan pembelajaran rutin setiap hari sabtu seperti belajar bersama dengan tutor sebaya terkait materi misalnya tentang keterampilan berbicara, belajar nahwu shorof bahkan belajar syair dan menyanyi dengan bahasa arab yang merupakan masuk kedalam program mingguan, dan adapun program bulanan biasanya dari anggota melaksanakan munaqosyah dan menerbitkan buletin terkait pembelajaran bahasa arab dan mengadakan evaluasi bulanan dari apa yang telah 
dilaksanakan setiap minggunya, kemudian ada program incidental biasanya program ini untuk mempersiapkan siswa-siswinya ikut dalam setiap event perlombaan gebyar bahasa arab, baik yang dilaksanakan di kampus-kampus ataupun di setiap sekolah sesuai dengan jenjang mereka ditingkat nasional sehingga perencanaan ini disebut sebagai perencanaan nasional, hal ini sesuai dengan teori bahwa ruang dan batasan wilayah sangat berkaitan dengan karakter yang dimiliki oleh perencanaan spasial yaitu perencanaan nasional karena kerangka penyusunan kerja berskala nasional. Dan teknis perencanaannya menggunakan perencanaan sektoral karena salah satu tujuan program ini ialah untuk menambah khazanah keilmuan dan keterampilan dalam bidang bahasa arab yang hal ini sejalan dengan tujuan pendidikan yaitu mencerdaskan para siswa dalam bidang bahasa arab dan ini sejalan dengan teori yang mengatakan bahwa perencanaan dari tingkatan teknis perencanaan salah satunya ialah perencanaan sektoral yaitu Perencanaa program dan kegiatan-kegiatan pendidikan untuk mencapai tujuan pendidikan nasional (Usman, 2008: 60).

Dengan adanya perencanaan program ini dapat mempermudah langkah kedepan untuk menyusun kegiatan dimasa yang akan datang untuk mencapai tujuan yang diinginkan. hal ini sesuai dengan penelitian yang dilakukan oleh Alchakim Amanu (2015: 90) sesuai pendapatnya bahwa program kerja berisi halhal yang akan dijalankan selama satu tahun kedepan, dengan perencanaan yang ada akan mempermudah langkah untuk tercapainya kepada tujuan program, bahkan MAN 1 Malang juga pernah menjadi tuan rumah dalam event besar kegiatan lomba gebyar bahasa arab di tingkat MA dan SMA se-Kota Malang dan acaranya bisa berjalan dengan lancar serta juga banyak dari anggota IPPBA ini yang berhasil menjadi juara dalam event perlombaan gebyar bahasa Arab tersebut.

Perencanaan program ini juga menggunkan perencanaan top down dan bottom up karena kegiatan yang ada dalam program ini dirancang secara bersama oleh ketua, para anggotanya dan tutor, misalnya materi pembelajaran setiap minggu dibuat secara bersama-sama oleh tutor tanpa saling mengandalkan setiap 
anggota yang terlibat di dalamnya. Hal ini sesuai dengan teori yang mengatakan bahwa Perencanaan Gabungan (top down dan bottom up) dibua toleh pemimpin dan juga anggotanya untuk kepentingan organisasi yang melibatkan partisipasi aktif keduanya (Usman, 2008: 85-86).

\section{Manajemen Pengorganisasian Program IPPBA MAN 1 Kota Malang}

Pada program IPPBA ini terdapat struktur pengorganisasian yang terdiri dari ketua, wakil ketua, sekertaris, bendahara, dan setiap anggota yang mempunyai tugas di setiap Co-nya masing-masing, dan ketua yang memegang penuh wewenang atau sebagai leader yang ada dalam organisasi IPPBA ini, hal ini sesuai juga dengan teori yang ada dalam prinsip struktur organisasi yaitu Departementalization (Depertamentalisasi) maksudnya adalah pemimpin mengelompokkan anggota beserta tugas-tugasnya (Wahab, 2008: 40-50). Karena dalam Pembagian kerja ini, Ketua IPPBA membaginya secara langsung sesuai dengan keahlian yang dimiliki oleh anggota, ketua memantau anggotanya yang mahir dalam bidang nahwu dan shorof maka akan dimasukkan dalam Sie Pembelajaran, begitu juga dengan yang lainnya. Sehingga setiap siswa dapat mempertanggungjawabkan setiap tugas dan fungsinya masing-masing dalam setiap kegiatan. Hal ini sesuai dengan teori bahwa adapun pengorganisasian merupakan proses membagi kerja ke dalam tugas yang lebih kecil, memberi tanggung jawab kepada setiap anggota yang sesuai dengan kemampuannya untuk mencapai tujuan yang diinginkan oleh suatu lembaga organisasi (Rahmawati, 2018: 59-60).

Bagan struktur organisasi di IPPBA ini menggunakan bagan struktur piramidal sebagaimana gambar berikut.

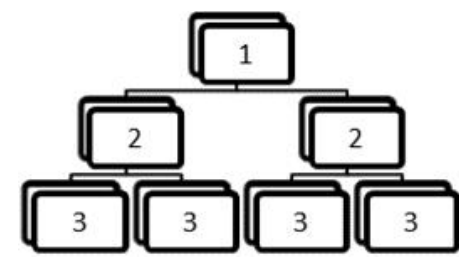


Keterangan : Di ketahui bahwa bagan nomor 1 diatas ditempati oleh ketua yang berfungsi sebagai pemimpin organisasi, bagan nomor 2 dari sisi kiri diisi oleh sekertaris 1 dan 2 dan bagan nomor 2 disisi kanan diisi oleh bendahara 1 dan 2, kemudian setiap bagan yang nomor 3 diisi oleh Co kegiatan masing-masing yang telah disepakati sesuai kebutuhannya. Sehingga dilihat dari bagannya posisi tertinggi dalam kewenangan mengatur dan mengkontrol setiap tugas ada pada ketua, dan sekertaris menjalankan tugasnya untuk membantu ketua dalam hal surat menyurat dan bendahara bertugas untuk mnejalankan tugasnya dalam hal pendanaan untuk dapat menjalankan segala kegiatan yang dilaksanakan, sedangkan setiap Co melaksanakan kegiatan, misalnya devisi pembelajaran tugasnya mengatur jalannnya materi dan menentukan materi yang akan diajarkan. Sehingga hal ini sesuai dengan pendapat arikunto (2017) dalam bukunya bahwa unit-unit dan pembagian tugas ini dapat melahirkan susunan kelompok kecil yang membentuk satu kelompok besar secara terstruktur dengan menggambarkan setiap unit pembagian tugasnya.

\section{F. Kesimpulan}

Program IPPBA berlangsung melalui dua proses yaitu:

\section{Perencanaan}

Perencanaan program IPPBA menggunakan perencanaan jangka pendek karena terdiri dari Program mingguan yaitu belajar bersama dengan tutor sebaya, dan program bulanan yaitu munaqosyah, menerbitkan buletin dan evaluasi, serta program incidental yaitu adanya perlombaan gebyar bahasa Arab untuk para siswa. Untuk dimensi spasial menggunakan perencanaan nasioal karena ada event gebyar bahasa Arab yang tujuannya sudah terlaksana ditingkat nasional. untuk tingkatan teknis perencanaan menggunakan perencanaan sektoral karena untuk mencerdaskan para siswa di bidang bahasa Arab. adapun jenis perencanaannya adalah top down dan bottom up karena kegiatan yang ada dalam program ini dirancang secara bersama oleh ketua, para anggotanya dan tutor serta atas kesepakatan bersama. 
2. Pengorganisasian

Pengorganisasian dilakukan oleh setiap pelaksana yang terdiri dari ketua, sekertaris, bendahara, dan Co-nya di bidang masing-masing. Dimana ketua mempunyai wewenang mengatur dan mengkontrol setiap tugas seluruh anggotanya, sekertaris dan bendahara membantu ketua sesuai tugasnya serta bagian Co-nya melaksanakan tugas menjalankan kegiatannya masing-masing

Sesuai fungsinya. Bagan struktur organisasi di IPPBA ini menggunakan bagan struktur piramidal sehingga dilihat dari bagannya posisi tertinggi dalam kewenangan mengatur dan mengkontrol setiap tugas ada pada ketua.

\section{Daftar Pustaka}

Amanu, Alchakim, 2015. Manajemen Pengembangan Bakat Minat Siswa di MTs AlWathoniyyah Pedurungan Semarang. Skripsi. UIN Walisongo.

Creswell, Jhon, Riset Pendidikan (Perencanaan, Pelaksanaan, dan Evaluasi Riset Kualitatif \& Kuantitatif. Yogyakarta: Pustaka Pelajar.

Majid, Abdul, 2005. Perencanaan Pembelajaran: Mengembangkan Standar Kompetensi Guru. Bandung: PT Remaja Rosdakarya.

Manab, Abdul, 2015. Manajemen Kurikulum Pembelajaran di Madrasah, Yogyakarta : Kalimedia.

Marno dan Triyo Supriyanto, Manajemen dan Kepemimpinan Pendidikan Islam, Bandung: PT. Refika Aditama.

Rahmawati, Alvi Dyah, 2018. Manajemen Pengorganisasian Program Kursus Bahasa Arab Di Pare Kediri. Malang : universitas maulana malik ibrahim malang. Vol. 3 No. 1. 59-60.

Siswanto, 2010. Pengantar Manajemen, Jakarta: PT. Bumi Aksara.

Sugiyono. 2017. Metode Penelitian Pendidikan: Pendekatan Kuantitatif, Kualitatif, dan $R \& D$. Bandung: Alfabeta.

Syukur, Fatah, 2015. Model Manajemen Madrasah Aliyah Efektif. Semarang : Universitas Islam Negeri Walisongo Semarang. Vol. 9. 474. 
Usman, Husaini, 2008. Manajemen Teori, Praktik, dan Riset Pendidikan. Jakarta: PT. Bumi Aksara.

Wahab, Abdul Aziz, 2008. Anatomi Organisasi dan Kepemimpinan Pendidikan, Bandung : Alfabeta.

Yusuf, Musfirotun, 2009. Membangun Manajemen Mutu Pendidikan Menghadapi Tantangan Global. Pekalongan: Jurusan Tarbiyah STAIN Pekalongan. Vol

7, Nomor 1.

Dzulqifly, Fawaz (ketua IPPBA), Wawancara oleh Ahmad Mujaddid, Rosiatul Fitriyah dan Siti Qomariyah. UIN Maulana Malik Ibrahim Malang. 1 Desember 2018.

Yasin (Waka Kesiswaan), Wawancara oleh Ahmad Mujaddid, Rosiatul Fitriyah dan Siti Qomariyah. UIN Maulana Malik Ibrahim Malang. 30 Nopember 2018 